\title{
Basal Dinantian miospores from the Cockermouth area, West Cumbria
}

\author{
M. A. BUTTERWORTH \& C. E. BUTCHER \\ Department of Geological Sciences, University of Aston, Birmingham B4 7ET \& \\ 27 Levinson Crescent, Balsall Common, Warwickshire
}

\begin{abstract}
Miospore assemblages are described from basal Dinantian argillaceous strata lying below and above the Cockermouth Lavas, and within the Seventh Limestone in the area to the north east of Cockermouth, West Cumbria. The strata enclosing the Lavas are assigned to the Schopfites claviger-Auroraspora macra miospore zone, indicating the Ivorian stage (Tournaisian, Tn 3). The Lavas are thus shown to be of similar age to the Solway Plateau Lavas to the north which represent an early stage in the formation of the Solway Basin.

Shales from below the Seventh Limestone are assigned to the Lycospora pusilla miospore zone and from this and other fossil evidence are presumed to be of Chadian or early Arundian age. Shales from within the Seventh Limestone are assigned to the Perotrilites tessellatus Schulzospora campyloptera miospore zone (Asbian stage)

It is concluded that the Ivcrian-Asbian sequence in this area is greatly attenuated compared with its development on the northern margin of the Solway Basin.
\end{abstract}

\section{INTRODUCTION}

Miospore assemblages have been examined from the Basement Conglomerate and from strata above the Cockermouth Lavas and associated with the Seventh Limestone in the area of West Cumbria lying to the north east of Cockermouth, on the northern flanks of the Lake District (Fig. 1).

The strata (c. 30 metres) below the lavas are termed the Basement Conglomerate (Eastwood et al., 1968) and lie with marked unconformity on the Skiddaw Slates. They are well exposed in Tommy Gill, Redmain (Grid Ref.: NY 138335). The Cockermouth Lavas die out eastwards and in the Uldale and Fellside areas the Basement Conglomerate lies unconformably on Eycott Lavas and is thicker, but seldom exposed. In both areas it consists of coarse conglomerates interbedded with grits, sandstones and mudstones, ranging in colour from grey-green to yellow and red, and sometimes with a calcareous cement.

The Cockermouth Lavas, olivine basalts of Dalmeny type, reach up to 100 metres in thickness. They overlie the unfossiliferous Basement Conglomerate and are succeeded by about 20 metres of interbedded shales, limestones and calcite mudstones which, together with the overlying Seventh and succeeding limestones, are assigned to the Lower Chief Limestone Group (Eastwood et al., loc. cit.). These strata crop out in Gill Beck (NY 149345), south of the Ghyll Yeat Inn in Blindcrake, which drains southwards into the River Derwent. Shackleton (1973), Butcher (1974) and Welsh (1980) give details of the section between the Cockermouth Lavas and the base of the Seventh Lime- stone, and there is a brief description by Eastwood et al. (loc. cit.) who record a shelly fauna in the uppermost shales. The 20 metres or so of exposed strata comprise mudstones with occasional shales and with three harder horizons of calcite mudstone containing Modiolus and ostracods, and forming small waterfalls. The highest calcite mudstone horizon is overlain by a metre of limestone breccia with quartz pebbles which makes a convenient marker horizon.

The earliest diagnostic fossils recorded in these Dinantian strata are the brachiopods and corals occurring in black shales immediately below the Seventh Limestone and in the limestone itself. According to Eastwood et al. (1968, pp. 160-161) these indicate the Nematophyllum minus (S2) zone and fossils normally restricted to the Lower Dibunophyllum Zone (D1) occur at the top of the Seventh Limestone. George et al. (1976) assign the Seventh Limestone to the Holkerian stage because of the presence of the characteristic Holkerian brachiopod Davidsonina carbonaria which Eastwood et al. record near its base. The Cockermouth Lavas and the unfossiliferous Basement Conglomerate are assumed to be of Arundian age by George et al. (1976, Fig. 11 ; in Table II the higher part of the Cockermouth Lavas is included in the Holkerian stage.)

Mitchell (1978, p. 173) states that corals recorded by earlier workers from low horizons in the Seventh Limestone at Beckermet to the south west and Berrier to the east of the present area are now identified as the late Chadian - early Arundian species Thysanophyllum pseudovermiculare; they are associated with typical 


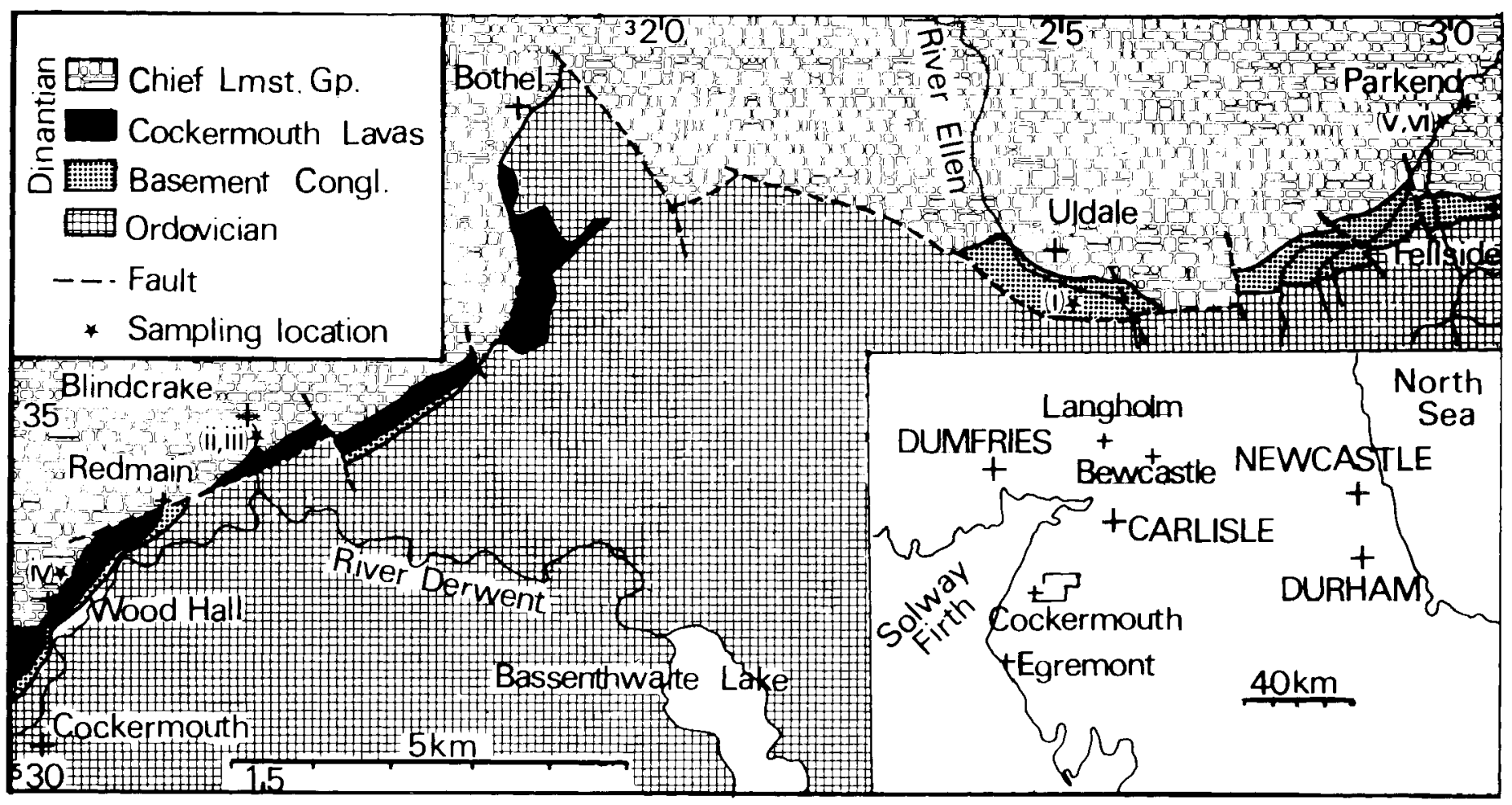

Fig.l. Map of sampling locations (based on Geological Survey Sheet 23, Cockermouth)

Arundian archaediscids. Mitchell believes that the shallow water conditions present in the lower parts of the Seventh Limestone may, therefore, represent the regressive part of the Arundian mesothem; the beds containing Davidsonina carbonaria would be deposited during the following Holkerian transgression and Mitchell (loc, cit., p. 174) notes that the restricted environment of the area during this time is indicated by the lack of diversity in the faunas and by the records of anhydrite etc. in the Seventh Limestone of the Egremont area to the south west (Llewellyn et. al., $1968)$

\section{MATERIAL STUDIED}

Six samples yielded reasonable miospore separations when macerated by standard procedures, i.e. removal of carbonates and silicates by hydrochloric and hydrofluoric acids and oxidation of the organic residues with fuming nitric acid.

(i) $30 \mathrm{~cm}$ grey mudstone underlain and overlain by red marls in the right bank of the stream al approximately 600 metres due south of the village of Uldale. Similar sediments were sampled at two points along the stream bank approximately 25 metres apart; these yielded comparable miospore assemblages and probably represent the same horizon in the Basement Conglomerate. (N Y 251366) (ii) 2 metres dark grey shales from near to the base of the Lower Chief Limestone Group, lying about 7 metres (strata unexposed) above the top of the Cockermouth Lavas in Gill Beck, Blindcrake. (NY 149345)

(iii) 2 metres fossiliferous grey shales from higher in the Lower Chief Limestone Group, lying above the limestone breccia and below the massive part of the Seventh Limestone at the top of the Gill Beck section. (NY 149346)

(iv) Carbonaceous band in the 6 metre limestone sequence exposed in an old quarry (NY 124327) near to Wood Hall. This is part of the Seventh Limestone which is faulted against the Cockermouth Lavas and which lies an unknown distance above the Gill Beck sequence.

(v) $10 \mathrm{~cm}$ black shales with occasional bryozoans interbedded with limestones in the left bank of Park End Beck. (N Y 297385)

(vi) $61 \mathrm{~cm}$ black shales rich in bryozoans interbedded with very fossiliferous limestones in the left bank of Park End Beck. (N Y 298385)

Samples (v) and (vi) are from the Bryozoa Band which occurs towards the top of the Seventh Limestone (Eastwood et al., 1968, p. 172).

Samples of fine-grained sediments in the Basement Conglomerate directly underlying the Cockermouth Lavas in Tommy Gill, Redmain were non-productive. 


\section{MIOSPORE ASSEMBLAGES}

Neves et al. (1972) defined eight concurrent range zones based on miospore distributions in the British Dinantian, and five of these were recognised in the Midland Valley of Scotland and in northern England by Neveset al (1973). Clayton et al. (1977) modified the limits of the zones and applied them to western Europe generally. Further modifications (Clayton et al., 1978) followed from comparative studies of miospore, conodont and foraminiferal distributions in the British Isles and the Ardennes.

The samples from the Basement Conglomerate (i) and the lowest part of the Lower Chief Limestone Group (ii) contain miospore assemblages dominated by Punctatisporites spp. and with significant numbers of Retusotriletes incohatus Sullivan, Crassispora trychere Neves \& Ioannides and Schopfites claviger Sullivan; the presence of the last two species together with the absence of Lycospora spp. indicates that the samples are almost certainly of Schopfites claviger - Auroraspora macra (CM) zone age. Other species present include Rugospora polyptycha Neves \& Ioannides, Colatisporites decorus (Bharadwaj \& Venkatachala) Williams, Grandispora echinata Hacquebard and A. macra Sullivan. The higher assemblage (ii) contains a more diverse microflora including Verrucosisporites nitidus (Naumova) Playford, Convolutispora spp., Pulvinispora quasilabrata Higgs, $P$. scolecophora Neves \& Ioannides and Spelaeotriletes pretiosus (Playford) Neves \& Belt.

The assemblage yielded by the shales above the limestone breccia in Gill Beck (iii) differs from those of samples (i) and (ii) in the absence of most of the species listed above and in the presence of high numbers of Prolycospora rugulosa (Butterworth \& Spinner) Turnau and some Lycospora noctuina Butterworth \& Williams and $L$. pusilla (Ibrahim) Somers. It is concluded that this horizon lies in the Lycospora pusilla $(\mathrm{Pu})$ zone as intensive searching yielded no evidence of Crassispora aculeata Neville, Schulzospora spp. or Perotrilites tessellatus (Staplin) Neville which characterise the overlying $P$. tessellatus $-S$. campyloptera (TC) zone.

The presence of abundant lycospores, common densospores, Schulzospora campyloptera (Waltz) Potonie \& Kremp and Dictyotriletes plumosus Butterworth \& Spinner in sample (iv) from Wood Hall, probably in the lower part of the Seventh Limestone, indicates the TC zone. Samples (v) and (vi) from the Bryozoa Band in Park End Beck, higher in the Seventh Limestone sequence, yielded similar but less varied assemblages; Prolycospora rugulosa is common in the lower of the two and Triquitrites comptus Williams appears in the higher sample. Clayton et al. (1977) indicate that Triquitrites spp. make their first appearance in the Raistrickia nigraTriquitrites marginatus (NM) zone but Williams (in Neves et al., 1973) records T. comptus from lower horizons, in the TC zone of the Brampton area. It is concluded therefore that all of the Seventh Limestone samples in the present study (iv, $v$ and vi) are from the TC zone.

\section{THE AGES OF THE MIOSPORE ASSEMBLAGES}

In their survey of Dinantian strata in Britain, George et al. (1976, Table I) indicate the relationships between their stages and the miospore zones of Neves et al. (1972). Ramsbottom \& Mitchell (1980) suggest that the lowest (Courceyan) stage should be replaced by the Belgian Hastarian and Ivorian stages, representing lower (Tn $1 \mathrm{~b}$ pars and $\operatorname{Tn} 2)$ and upper $(\operatorname{Tn} 3)$ parts of the Tournaisian series respectively; in their Table 1 the CM zone falls within the Ivorian stage and the base of the $\mathrm{Pu}$ zone coincides with the base of the Chadian stage and the base of the Visean series. George et al. (loc. cit.) and Clayton et al. (1978) indicate that the Pu zone extends through the Chadian, Arundian and Holkerian stages with the overlying TC zone having a common base with the Asbian stage.

It follows from the present investigations, therefore, that the $\mathrm{CM}$ zone samples from the Basement Conglomerate (i) and from just above the Cockermouth Lavas (ii) are Ivorian in age. The Pu zone sample (iii) from above the limestone breccia in Gill Beck could be of any age from Chadian to Holkerian.

The presence of high numbers of Prolycospora rugulosa does not help to shorten this possible range; similar abundances are present in black shales sampled in Tarras Water, Langholm, from the highest part of the Lower Border Group (M.A.B., unpublished data) which George et al. (1976) assign to the upper part of the Courceyan stage (Ivorian stage of Ramsbottom \& Mitchell, 1980), and Butterworth \& Spinner (1967) record high numbers from horizons in the Chadian and Holkerian stages in addition to the Lewisburn type locality of presumed Asbian age. P. rugulosa thus has a long stratigraphic range and its local abundance must be due to unknown ecological factors.

The TC zone sample (iv), (v) and (vi), from shales within the Seventh Limestone, have miospore assemblages consistent with an Asbian age.

\section{DISCUSSION}

The miospore assemblages recorded from the Basement Conglomerate and the lower part of the Lower Chief Limestone Group suggest that these strata, and the included Cockermouth lavas, are older than the Arundian age previously suggested (George et al., 1976). They are of a similar (Ivorian) age to other basal Carboniferous strata flanking the Lake District (Holliday, Neves \& Owens, 1979; Welsh, 1980).

The Cockermouth Lavas are of similar type to the Kelso Traps of the Tweed Basin and to the Birrenswark Lavas of Dumfriesshire which George et al. (loc. cit.) state to be middle low Courceyan in age; they could therefore form a part of the Solway Plateau Lavas 
postulated by Geikie (1897) and later believed by Leeder (1974) to represent an early stage in the formation of the Solway Basin.

The $\mathrm{Pu}$ zone assemblage recorded from the black shales (iii) above the limestone breccia in Gill Beck could be from the Chadian, Arundian or Holkerian stages. However, the presence of the late Chadian - early Arundian coral Thysanophyllum pseudovermiculare and Arundian archaediscid foraminifera recorded at similar or slightly higher horizons elsewhere in the area (Mitchell, 1978, p. 173) suggests that the shales overlying the breccia are of Chadian or early Arundian age.

The TC zone (Asbian) age of miospore assemblages from black shales within the more massive parts of the Seventh Limestone (samples iv, $\mathrm{v}$ and vi) are presumably from higher horizons than the beds containing the Holkerian brachiopod Davidsonina carbonaria which occurs near to its base (George et al., 1976). The age based on miospores is in accord with the presence of $\mathrm{D}_{1}$ (Asbian) fossils recorded by Eastwood et al (1968) at the top of the Seventh Limestone.

It follows from the above that the strata representing the Chadian, Arundian and Holkerian stages in this area are greatly reduced in thickness compared with their development to the east and north where extensive sandstone deltas were forming along the northern margin of the Solway Basin.

\section{ACKNOWLEDGEMENTS}

Part of this work was carried out by one of the authors (C.E.B.) during the tenure of a research studentship in the Department of Geological Sciences, University of Aston.

\section{REFERENCES}

Butcher, C.E. 1974. Carboniferous miospore distributions in Cumberland with special reference to those in the Hensingham Group. Unpublished Ph.D. thesis, University of Aston.

Butterworth, M. A. \& Spinner, E. 1967. Lower Carboniferous spores from north-west England. Palaeontology, London, 10, $1-24$.

Clayton, G., Coquel, R., Doubinger, J., Gueinn, K. J., Loboziak, S., Owens, B. \& Streel, M. 1977. Carboniferous miospores of Western Europe: illustration and zonation. Meded. Rijks Geol. Dienst., Leiden, 29, 1-71.

Clayton, G., Higgs, K., Keegan, J.B. \& Sevastopulo, G.D. 1978. Correlation of the palynological zonation of the Dinantian of the British Isles. Palinologia, 1, 137-147.

Eastwood, T., Hollingworth, S.E., Rose, W.C.C. \& Trotter, F.M. 1968. Geology of the country around Cockermouth and Caldbeck. Mem. geol. Surv. U.K. $\times+298$ pp.

Geikie, A. 1897. The ancient volcanoes of Great Britain. (2 vols.) London.

George, T.N., Johnson, G.A.L., Mitchell, M., Prentice, J.E., Ramsbottom, W.H.C., Sevastopulo, G.D. \& Wilson, R.B 1976. A correlation of Dinantian rocks in the British Isles. Geol. Soc. Lond., Special Report No. 7, 87 pp.

Holliday, D.W., Neves, R. \& Owens, B. 1979. Stratigraphy and palynology of early Dinantian (Carboniferous) strata in shallow boreholes at Ravenstonedale, Cumbria. Proc. Yorks. geol. Soc., 42, 343-356.

Leeder, M. 1974. The origin of the Northumberland Basin. Scott. J. Geol., Edinburgh, 10, 283-296.

Llewellyn, P.G., Mahmoud, S.A. \& Stabbins, R. 1968 Nodular anhydrite in Carboniferous Limestone, Cumberland. Trans. Instn. Min. Metall. (Sect. B: Appl. earth Sci.), London, 77, B18-25.

Mitchell, M. 1978. In Moseley, F. (Ed.), The Geology of the Lake District. Yorks. geol. Soc. Occasional Publication No. 3, 284 pp.

Neves, R., Gueinn, K.J., Clayton, G., Ioannides, N.S. \& Neville, R.S.A. 1972. A scheme of miospore zones for the British Dinantian. C.R. 7th Congr. Int. Carb. Strat. Geol., Krefeld (1971), 1, 347-353.

Neves, R., Gueinn, K.J., Clayton, G., Ioannides, N.S., Neville, R.S.A. \& Kruszewska, K. 1973. Palynological correlations within the Lower Carboniferous of Scotland and Northern England. Trans. roy. Soc. Edinb., 69, 23-70.

Ramsbottom, W.H.C. \& Mitchell, M. 1980. The recognition of the Tournaisian Series in Britain. Jl. geol. Soc. London, 137, 61-63.

Shackleton, E.H. 1973. Lakeland Geology. Dalesman Books, Clapham, Yorkshire.

Welsh, A. 1980. Stratigraphical palynology of early Dinantian strata in Cumbria. Unpublished Ph.D. thesis, University of Sheffield. 